\title{
ASIAN CONNECTIONS
}

Edited by Timothy Brook, Engseng Ho and Iza Hussin

1. PRASENJIT DUARA

The Crisis of Global Modernity

Asian Traditions and a Sustainable Future

HB 9781107082250

PB 9781107442856

2. EVELYN S. RAWSKI

Early Modern China and Northeast Asia

Cross-Border Perspectives

HB 9781107093089

PB 9781107471528

3. SU LIN LEWIS

Cities in Motion

Urban Life and Cosmopolitanism in Southeast Asia, 1920-1940

HB 9781107108332

PB 9781316647493

4. FAHAD AHMAD BISHARA

A Sea of Debt

Law and Economic Life in the Western Indian Ocean, 1780-1950

HB 9781107155657

PB 9781316609378

5. SUMIT K. MANDAL

Becoming Arab

Creole Histories and Modern Identity in the Malay World

HB 9781107196797

PB 9781316647493

6. DAVID R. AMBARAS

Japan's Imperial Underworlds

Intimate Encounters at the Borders of Empire

HB 9781108470117

PB 9781108455220

7. ELIZABETH A. LAMBOURN

Abraham's Luggage

A Social Life of Things in the Medieval Indian Ocean World

HB 9781107173880

PB 9781316626276 
8. RONIT RICCI

Banishment and Belonging

Exile and Diaspora in Sarandib, Lanka and Ceylon

HB 9781108480277

PB 9781108727242

9. MARIEKE BLOEMBERGEN AND MARTIJN EICKHOFF The Politics of Heritage in Indonesia

A Cultural History

HB 9781108499026

10. TEREN SEVEA

Miracles and Material Life

Rice, Ore, Traps and Guns in Islamic Malaya

HB 9781108477185

11. HYUNHEE PARK

Soju

A Global History

HB 9781108842013

12. MAGNUS MARSDEN

Beyond the Silk Roads

Trade, Mobility and Geopolitics across Eurasia HB 9781108838313 
